\title{
Retention of Resistance to Fusarium oxysporum f. sp. niveum in Cucurbit Rootstocks Infected by Meloidogyne incognita
}

\author{
Anthony P. Keinath ${ }^{\dagger}$ and Paula A. Agudelo, Department of Plant and Environmental Sciences, Clemson University, Clemson, SC 29634- \\ 0310
}

\begin{abstract}
Interspecific hybrid squash (Cucurbita maxima $\times$ C. moschata 'Strong Tosa') and bottle gourd (Lagenaria siceraria 'Macis') rootstocks are resistant to Fusarium oxysporum f. sp. niveum but susceptible to Meloidogyne incognita (Southern root-knot nematode). Coinfection of Early Prolific Straightneck summer squash (C. pepo) with root-knot nematode and $F$. oxysporum f. sp. niveum has been reported to increase susceptibility to Fusarium wilt. The objectives of this study were to determine whether such an interaction occurred between $M$. incognita and $F$. oxysporum f. sp. niveum races 1 and 2 on Strong Tosa, Macis, and watermelon cultivars Fascination (resistant to race 1) and Tri-X 313 (susceptible to both races). Hosts were inoculated in a greenhouse with one of four pathogen treatments: $F$. oxysporum f. sp. niveum, $M$. incognita, both pathogens, or neither pathogen. Galling was present on $\geq 10 \%$ of the root systems of $90 \%$ of the plants inoculated with $M$. incognita. Bottle gourd had less galling

than interspecific hybrid squash. Plants not inoculated with $F$. oxysporum f. sp. niveum did not wilt. Four weeks after inoculation, incidence and severity of Fusarium wilt and recovery of $F$. oxysporum did not differ for any hosts inoculated with $F$. oxysporum $\mathrm{f}$. sp. niveum alone and $F$. oxysporum f. sp. niveum plus $M$. incognita (host-treatment interactions not significant). In general, Early Prolific Straightneck grouped with the $F$. oxysporum f. sp. niveum-resistant rootstocks when inoculated with $F$. oxysporum $\mathrm{f}$. sp. niveum race 2 and with the susceptible watermelon when inoculated with race 1, regardless of inoculation with $M$. incognita. Recovery of $F$. oxysporum from stems of inoculated watermelon was greater than recovery from the other three hosts, regardless of nematode inoculation. In conclusion, our experiments do not support the hypothesis that resistance to $F$. oxysporum f. sp. niveum in cucurbit rootstocks or resistant watermelon cultivars would be compromised when $M$. incognita infects the roots.
\end{abstract}

Fusarium wilt of watermelon (Citrullus lanatus var. lanatus (Thunb.) Matsum. \& Nakai), caused by Fusarium oxysporum f. sp. niveum W. C. Snyder \& H. N. Hansen, is considered the "most economically important disease of watermelon globally" (Martyn 2014). Although four races, designated $0,1,2$, and 3, have been reported, races 1 and 2 are currently the most important (Zhou et al. 2010). Races 1 and 2 are widely distributed within the United States and other leading watermelon-producing countries (Martyn 2017). Diploid and triploid watermelon cultivars with resistance to race 1 are commercially available and used widely in the southern United States (Kemble et al. 2017). Although sources of resistance to race 2 have been identified in $C$. lanatus var. citroides, watermelon cultivars that possess this resistance are not yet available (Wechter et al. 2012). In place of watermelon cultivars resistant to Fusarium wilt, grafting susceptible scions onto bottle gourd (Lagenaria siceraria (Molina) Standl.) and interspecific hybrid squash (Cucurbita maxima Duch. ex Lam. $\times$ C. moschata Duch. ex Poir) rootstocks protects grafted plants from Fusarium wilt (Davis et al. 2008; Keinath and Hassell 2014b; Martyn 2017). Both rootstock genera are resistant to $F$. oxysporum f. sp. niveum races 1 and 2 (Keinath and Hassell 2014a; Yetışır et al. 2003). Thus, grafting is effective regardless of which race is present or predominates in a field.

In soil infested with Meloidogyne incognita, watermelon, bottle gourd, and interspecific hybrid squash are likely to be infected by the Southern root-knot nematode (Thies 2017; Thies et al. 2010). Coinfection of hosts by $M$. incognita and formae speciales of $F$. oxysporum may lead to at least four different outcomes. Coinfection is

${ }^{\dagger}$ Corresponding author: A. P. Keinath; E-mail: tknth@clemson.edu

Funding: This material is based upon work that is supported, in part, by the United States Department of Agriculture National Institute of Food and Agriculture, under award number 2011-51181-30963 and project numbers SC1700536 and SC-1700522. Technical Contribution number 6608, Clemson University Experiment Station.

Accepted for publication 26 March 2018.

() 2018 The American Phytopathological Society known to induce wilt symptoms in Fusarium wilt-resistant cotton and melon (Cucumis melo) cultivars (Bell et al. 2017; Naji and Abu-Gharbieh 2004). Coinfection of summer squash (Cucurbita pepo 'Early Prolific Straightneck') by $M$. incognita and $F$. oxysporum $\mathrm{f}$. sp. niveum race 1 altered the nonhost response of summer squash so that twice as many plants wilted as when squash was inoculated with $F$. oxysporum f. sp. niveum alone (Caperton et al. 1986). Although coinfection by $F$. oxysporum f. sp. lycopersici and Southern root-knot nematode increases incidence and severity of Fusarium wilt in wilt-susceptible tomato cultivars, coinfection of wilt-resistant cultivars does not affect resistance (Noling 2014). In other hostpathogen systems, such as $F$. oxysporum f. sp. ciceris and $M$. artiellia, coinfection has no impact on either susceptible or resistant cultivars of chickpea (Navas-Cortés et al. 2008).

Only two previous studies have examined a potential interaction between $M$. incognita and $F$. oxysporum $\mathrm{f}$. sp. niveum on watermelon. Using naturally infested field soils, Sumner and Johnson (1973) reported that mean wilt incidence was greater in soils with both pathogens than in soil with only $F$. oxysporum f. sp. niveum race 1. However, soils infested with $M$. incognita also had more CFU of $F$. oxysporum f. sp. niveum; therefore, the effects of $F$. oxysporum f. sp. niveum inoculum density and $M$. incognita infestation could not be distinguished. Moreover, the data were not analyzed statistically (Sumner and Johnson 1973). In a very recently published study, no differences in Fusarium wilt severity were observed when watermelon or three nonhost cucurbits, including interspecific hybrid squash, were inoculated with $F$. oxysporum f. sp. niveum or $F$. oxysporum $\mathrm{f}$. sp. niveum plus $M$. incognita. The race of the $F$. oxysporum $\mathrm{f}$. sp. niveum isolate used and the resistance of the single watermelon cultivar were not reported (Seo and Kim 2017). Thus, neither report provides conclusive evidence for or against an interaction of $F$. oxysporum $\mathrm{f}$. sp. niveum and $M$. incognita.

Young watermelon plants with symptoms of Fusarium wilt and root galling were observed in spring 2012 in three fields on a large commercial farm in South Carolina (A. P. Keinath, personal observation). The plants had been transplanted approximately 3 to 4 weeks earlier. Spring 2012 was unusually warm in the eastern United States; thus, $M$. incognita likely was active earlier than normal. This observation provides evidence that both pathogens can coinfect fieldgrown watermelon early in the crop growth cycle. The objectives 
of this study were to determine whether coinoculation of watermelon, bottle gourd, and interspecific hybrid squash with $F$. oxysporum $\mathrm{f}$. sp. niveum and $M$. incognita altered the race-specific resistance of watermelon or the nonhost resistance of the rootstocks to $F$. oxysporum f. sp. niveum. Summer squash Early Prolific Straightneck was included as a positive control treatment that previously exhibited increased susceptibility to $F$. oxysporum $\mathrm{f}$. sp. niveum race 1 when infected by M. incognita (Caperton et al. 1986).

\section{Materials and Methods}

Three experiments were done in a greenhouse at the Clemson University Coastal Research and Education Center, Charleston, SC. The experimental design was a split plot with host cultivar as the whole plot and pathogen treatment as the subplot. $F$. oxysporum f. sp. niveum race 2 was used in the first experiment, $F$. oxysporum f. sp. niveum race 1 was used in the second experiment, and both races were inoculated separately in the third experiment. Each experiment was done twice, and each repetition is referred to as a trial below. In the first and second experiment, each host-pathogen treatment combination, including the noninoculated control treatments, included 12 plants. In the third experiment, each host-pathogen treatment combination for each $F$. oxysporum $\mathrm{f}$. sp. niveum race included six plants.

Watermelon cultivars were seeded 4,4 , and 3 weeks prior to transplanting in experiments one, two, and three, respectively; and bottle gourd, interspecific hybrid squash, and summer squash were seeded 2,3 , and 2 weeks prior to transplanting in experiments one, two, and three, respectively, to ensure that all cultivars had a fully expanded second true leaf at the time of inoculation (Table 1) (Keinath and Hassell 2014a; Miguel et al. 2004). Seed were sown in 98-cell plug trays with cells $5.1 \mathrm{~cm}$ deep and $3.4 \mathrm{~cm}$ wide filled with Fafard 3B soil mix (Sun Gro Horticulture, Agawam, MA). All plants were transplanted into pots $15.2 \mathrm{~cm}$ in diameter and $11.4 \mathrm{~cm}$ deep filled with Fafard 3B soil mix and watered after transplanting before inoculation.

To prepare inoculum, isolates of $F$. oxysporum $\mathrm{f}$. sp. niveum were grown on quarter-strength potato dextrose agar for 14 days. Two 0.7$\mathrm{cm}$-diameter pieces of agar with mycelium were added to $100 \mathrm{ml}$ of sterile potato dextrose broth and grown on a shaker table at $130 \mathrm{rpm}$ for 7 to 10 days at $22^{\circ} \mathrm{C}$. The broth was filtered through two layers of sterile cheesecloth. The concentration of microconidia was adjusted to $10^{6} \mathrm{microconidia} / \mathrm{ml}$ in all three experiments, except that $5 \times 10^{5}$ microconidia/ml was used in the second trial of the experiment with $F$. oxysporum f. sp. niveum race 2 . Inoculum was applied immediately after transplanting by depositing $10 \mathrm{ml}$ of conidial suspension into two holes, $0.5 \mathrm{~cm}$ wide by $3 \mathrm{~cm}$ deep and $180^{\circ}$ apart, centered on the plant. Water was applied to the treatments not receiving F. oxysporum f. sp. niveum inoculum.

$M$. incognita race 3, originally isolated from a field cropped to soybean and cotton in Barnwell County, SC, was maintained on tomato in a greenhouse. Galled roots were cut into 1-cm-long pieces and agitated for $4 \mathrm{~min}$ in a solution of $0.5 \%$ sodium hypochlorite. The solution was poured through two stacked sieves with $0.074-$ and $0.037-\mathrm{mm}$ openings. Eggs retained on the $0.037-\mathrm{mm}$ sieve were held in water at $28^{\circ} \mathrm{C}$ for 4 to 6 days to allow the second-stage juveniles (J2) to hatch. The suspension of J2 nematodes was applied to pots immediately after transplanting by depositing $1 \mathrm{ml}$ of a suspension of
$1,000 \mathrm{~J} 2$ nematodes $/ \mathrm{ml}$ into two holes, $0.5 \mathrm{~cm}$ wide by $1.5 \mathrm{~cm}$ deep and $180^{\circ}$ apart, centered on the plant and perpendicular to the inoculation sites for $F$. oxysporum f. sp. niveum. In the first trial of the experiment with $F$. oxysporum $\mathrm{f}$. sp. niveum race $2,3 \mathrm{ml}$ of nematode inoculum was applied. Water was applied to the treatments not receiving $M$. incognita inoculum.

Inoculated and noninoculated plants were maintained in a greenhouse at 24 to $27^{\circ} \mathrm{C}$ for 4 weeks. Plants were checked for symptoms of wilting 2 and 3 weeks after inoculation. Wilt severity was estimated visually on a 0 to $100 \%$ scale in $10 \%$ increments. Plants with wilt severity $\geq 70 \%$ were removed from the pots, and the root systems were washed under running tap water to remove potting soil. The percentage of the root system with galls was estimated visually on a 0 -to- $100 \%$ scale in $10 \%$ increments. At 4 weeks after inoculation, all remaining plants were removed from pots, and roots were washed and rated for galling.

In the two trials of the last experiment that included both $F$. oxysporum f. sp. niveum races, all plants were checked for colonization by $F$. oxysporum. Two $0.5-\mathrm{cm}$-long pieces were cut from the base of the main stem of each plant at 2 or 3 weeks after inoculation if wilt severity was $\geq 70 \%$ and at 4 weeks after inoculation for all remaining plants. Scissors used to cut plants were flame sterilized between plants. Stem pieces were surface disinfested for $1.5 \mathrm{~min}$ with $0.6 \%$ sodium hypochlorite, rinsed in sterile water, and placed on Komada's agar medium to determine whether $F$. oxysporum was present in the piece (Komada 1975). Plates were held at 20 to $22^{\circ} \mathrm{C}$ with a 16 -h day length. After 7 days, colonies resembling $F$. oxysporum were counted based on color (white to pale orange or salmon) and texture (dense and fluffy) of aerial mycelium and abaxial colony color (dull purple to purple-brown) (Kleczewski and Egel 2011; Komada 1975).

Data on severity of galling and severity of Fusarium wilt were analyzed with a mixed-model maximum-likelihood analysis (PROC MIXED, SAS version 9.4; SAS Institute Inc., Cary, NC), with experiment or trial, host, pathogen inoculation, and their interactions as fixed effects and block as a random effect. To be able to draw broader conclusions beyond the individual experiments, the effects of trial and interactions with trial were tested as random effects on galling severity (Schabenberger and Pierce 2002). Severity of Fusarium wilt was analyzed separately by race, because of the race-specific resistance in Fascination watermelon (Table 1). Before analysis, percentage severities were transformed with arcsine of the square root to correct for nonnormality and inequality of variances among treatments. Residuals from analysis of variance were checked for nonnormality and inequality of variance with PROC UNIVARIATE. Back-transformed least-squares means are shown in the tables. Treatment means were compared with Fisher's least significant difference test.

Data on incidence of Fusarium wilt and recovery of F. oxysporum from plants were analyzed using SAS PROC CATMOD for categorical data, which uses a $\chi^{2}$ statistic to determine treatment effects. Incidence of Fusarium wilt was analyzed separately by race, because of the race-specific resistance in Fascination watermelon (Table 1). Incidence and the proportions of plants from which $F$. oxysporum was or was not recovered were transformed by calculating the logit, and the linear model parameters were then estimated using the maximumlikelihood option. In order to get models that included zero values for some categories to converge (i.e., arrive at a unique solution),

Table 1. Cultivars of cucurbits used in all experiments

\begin{tabular}{lllccc}
\hline & & & \multicolumn{2}{c}{ Reaction to inoculation } \\
\cline { 3 - 5 } Cultivar & \multicolumn{1}{c}{ Common name } & Latin binomial & F. oxy race 1 & F. oxy race 2 & Meloidogyne incognita \\
\hline Tri-X 313 & Triploid watermelon & Citrullus lanatus & $\mathrm{S}$ & $\mathrm{S}$ & $\mathrm{S}$ \\
Fascination & Triploid watermelon & C. lanatus & $\mathrm{MR}$ & $\mathrm{S}$ & $\mathrm{S}$ \\
Early Prolific Straightneck & Yellow summer squash & Cucurbita pepo & $\mathrm{MS}$ & $\mathrm{R}^{\mathrm{z}}$ & $\mathrm{R}$ \\
Macis & Bottle gourd & Lagenaria siceraria & $\mathrm{R}$ & $\mathrm{S}$ \\
Strong Tosa & Interspecific hybrid squash & C. maxima $\times$ C. moschata & $\mathrm{R}$ & $\mathrm{R}$ & $\mathrm{S}$ \\
\hline
\end{tabular}

${ }^{\text {y }}$ F. oxy $=$ Fusarium oxysporum $\mathrm{f}$. sp. niveum. $\mathrm{S}=$ susceptible ( $>80 \%$ wilt incidence), $\mathrm{MS}=$ moderately susceptible $(51$ to $80 \%$ wilt incidence), MR $=$ moderately resistant ( 21 to $50 \%$ wilt incidence), and $\mathrm{R}=$ resistant ( $\leq 20 \%$ wilt incidence) (Martyn and McLaughlin $1983 \mathrm{~b})$.

${ }^{\mathrm{z}}$ Unknown at the start of this study. 
observed proportions were replaced with a Bayes estimator calculated as $x=[c t+(k / r)] \times n /(n+k)$, where $x=$ the weighted proportion, $c t=$ count of plants with (or without) symptoms or $F$. oxysporum, $r=$ 2 (for a binary response), $k=$ a constant that was set equal to $r$, and $n=$ total number of plants per treatment combination (Santner and Duffy 1989). Stepwise model reduction was done to improve the sensitivity of the analysis. When treatment effects were significant, contrast statements were written to compare hosts and pathogen treatments. Interactions of pathogen and host were examined by comparing hosts within pathogen treatments or pathogen treatments within hosts. Proportions were generated using the predict option to back-transform logit values.

\section{Results}

Root-knot. Across all six experiments, $91 \%$ of the 620 plants inoculated with $M$. incognita or $M$. incognita plus $F$. oxysporum $\mathrm{f}$. sp. niveum had galls on $\geq 10 \%$ of their root systems. Only 1 of 620 plants not inoculated with $M$. incognita had any galls, a summer squash plant inoculated with $F$. oxysporum $\mathrm{f}$. sp. niveum race 1 alone that had galls on $10 \%$ of its root system. In experiment one, mean percent root system galled in the $M$. incognita treatment was 34 and $48 \%$ in trials one and two when each plant was inoculated with 3,000 and 2,000 J2 nematodes, respectively. Thus, 2,000 J2 were considered a sufficient inoculum level in all subsequent trials.

Pathogen treatments. Data from treatments without $M$. incognita were excluded from the analysis to avoid inequality of variance among treatments. In the first experiment, which included $F$. oxysporum f. sp. niveum race 2 , the host-pathogen interaction was not significant ( $F$ statistic, $P \leq 0.21$ ). Percent root system galled did not differ between plants inoculated with $M$. incognita alone and plants inoculated with $M$. incognita plus $F$. oxysporum $\mathrm{f}$. sp. niveum race 2 (Fig. 1A). However, in the second and third experiments, the host-pathogen interaction was highly significant ( $F$ statistic, $P \leq 0.0001)$. In these two experiments, galling on the Fusarium wilt-susceptible Tri-X 313 watermelon was more severe on root systems inoculated with $M$. incognita alone than on root systems coinoculated with $F$. oxysporum f. sp. niveum and $M$. incognita $(P \leq 0.01)$, due to early senescence of watermelon roots infected by $F$. oxysporum f. sp. niveum in the latter treatment (Fig. $1 \mathrm{~B}, \mathrm{C}$, and D). Likewise, galling on Fascination watermelon was more severe in the third experiment when it was inoculated with $M$. incognita alone than with $F$. oxysporum $\mathrm{f}$. sp. niveum and $M$. incognita (Fig. 1C and D), although this treatment difference was not observed in the first two experiments (Fig. 1A and B). In contrast, $M$. incognita alone and $M$. incognita plus $F$. oxysporum f. sp. niveum caused similar levels of galling on Strong Tosa interspecific hybrid squash and Macis bottle gourd in all three experiments and with both races (Fig. 1). Likewise, galling was equally severe with or without F. oxysporum f. sp. niveum on Early Prolific Straightneck summer squash in the first and third experiments (Fig. 1A, C, and D) but not in the second experiment (Fig. 1B), when F. oxysporum f. sp. niveum race 1 was used.

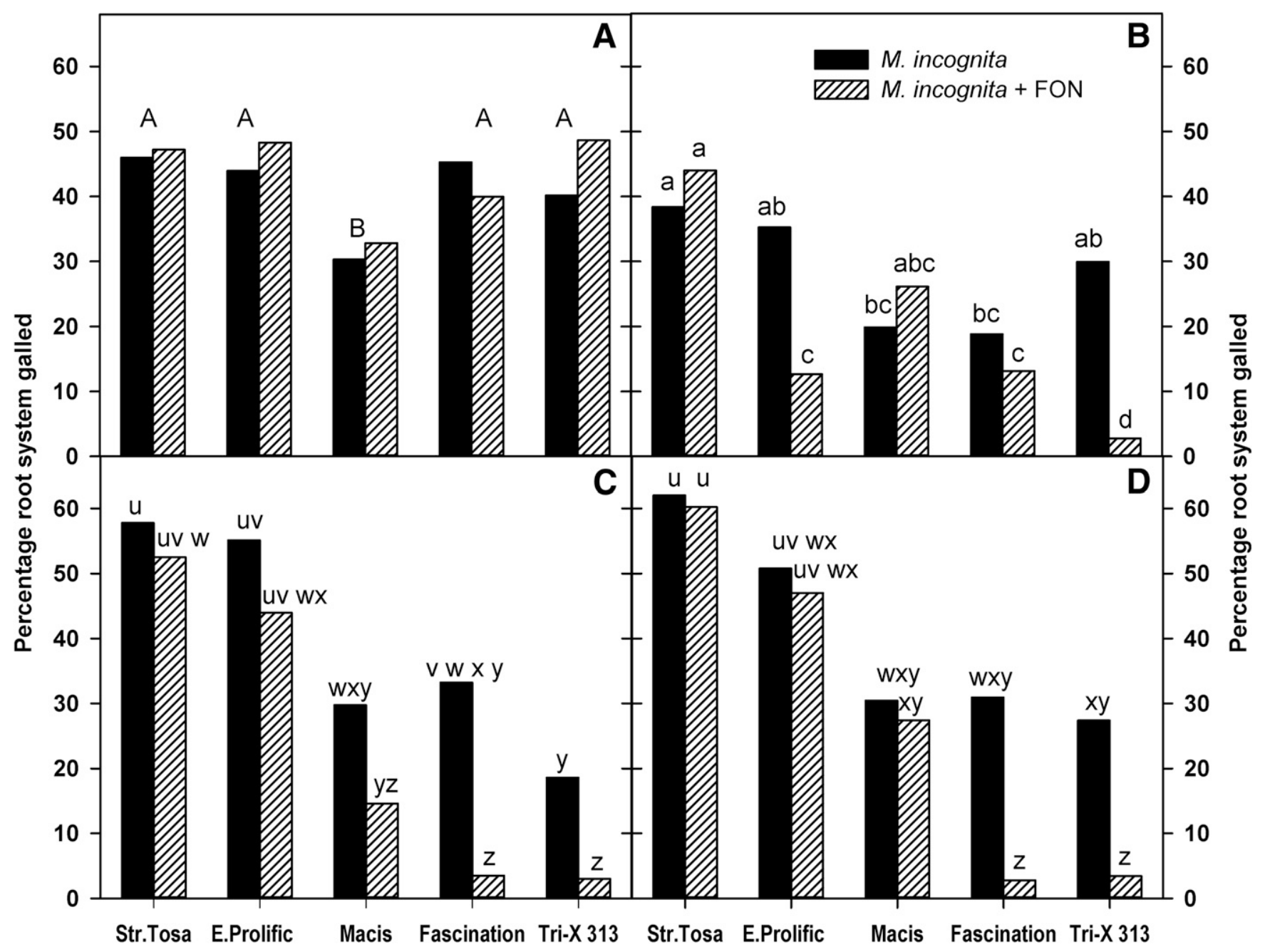

Fig. 1. Mean percentage of the root system with galls on five cucurbits inoculated with Meloidogyne incognita or M. incognita plus Fusarium oxysporum f. sp. niveum in the greenhouse. Each graph shows the mean of two trials. A, F. oxysporum f. sp. niveum race 2, experiment one. Bars for hosts with the same uppercase letters are not significantly different $(P=0.01)$. B, $F$. oxysporum f. sp. niveum race 1 , experiment two. Bars with the same lowercase letters are not significantly different $(P=0.01)$. C, F. oxysporum f. sp. niveum race 2, experiment three. D, F. oxysporum f. sp. niveum race 1 , experiment three. Bars in $C$ or $D$ with the same lowercase letters are not significantly different $(P=0.01)$. 
Host treatments. In all three experiments, roots of Macis bottle gourd were less severely galled $(P \leq 0.01)$ than roots of Strong Tosa interspecific hybrid squash when these two hosts were inoculated with $M$. incognita alone (Fig. 1). Fascination watermelon inoculated with $M$. incognita alone also was less severely galled than Strong Tosa in the second and third experiments (Fig. 1B, C, and D) but not in the first experiment (Fig. 1A). Severity of galling did not differ significantly among Macis, Fascination, or Tri-X 313 inoculated with $M$. incognita alone in the second and third experiments. Severity of galling did not differ between Strong Tosa interspecific hybrid squash and Early Prolific Straightneck summer squash inoculated with $M$. incognita alone in any experiment.

Hosts responded to inoculation with $M$. incognita plus $F$. oxysporum f. sp. niveum in a manner that was similar to their responses to $M$. incognita alone. Roots of Macis bottle gourd were less severely galled $(P \leq 0.01)$ than roots of Strong Tosa interspecific hybrid squash in experiments one and three (Fig. 1A, C, and D), although this difference was not observed in experiment two (Fig. 1B). Fascination watermelon inoculated with $M$. incognita plus $F$. oxysporum f. sp. niveum also was less severely galled than Strong Tosa in the second and third experiments, due to early senescence of watermelon roots infected by $F$. oxysporum f. sp. niveum in the treatment with both pathogens (Fig. 1B, C, and D) but not in the first experiment (Fig. 1A). Likewise, galling was less severe on Tri-X 313 watermelon roots than on roots of Early Prolific Straightneck summer squash in experiments two and three. Severity of galling did not differ between interspecific hybrid squash and summer squash inoculated with $M$. incognita plus $F$. oxysporum $\mathrm{f}$. sp. niveum in experiments one and three (Fig. 1A, C, D) but Early Prolific Straightneck had significantly $(P \leq 0.01)$ less galling than Strong Tosa in experiment two (Fig. 1B), due to early senescence of roots infected by $F$. oxysporum $\mathrm{f}$. sp. niveum race 1 in the treatment with both pathogens.

Fusarium wilt. Wilt incidence. When inoculated with $F$. oxysporum f. sp. niveum race 2 in experiments one and three, most (>70\%) Tri-X 313 and Fascination watermelon plants wilted, regardless of whether M. incognita was present (Fig. 2A and C), because both cultivars are susceptible to $F$. oxysporum $\mathrm{f}$. sp. niveum race 2. Although one to two Early Prolific Straightneck summer squash plants wilted when inoculated with $F$. oxysporum $\mathrm{f}$. sp. niveum race 2 or $F$. oxysporum f. sp. niveum race 2 plus $M$. incognita in experiment three (Fig. 2C), the proportion of wilted plants did not differ significantly among the four pathogen treatments $(P=0.62)$. No Macis bottle gourd or Strong Tosa interspecific hybrid squash plants wilted, regardless of treatment (Fig. 2A and C).

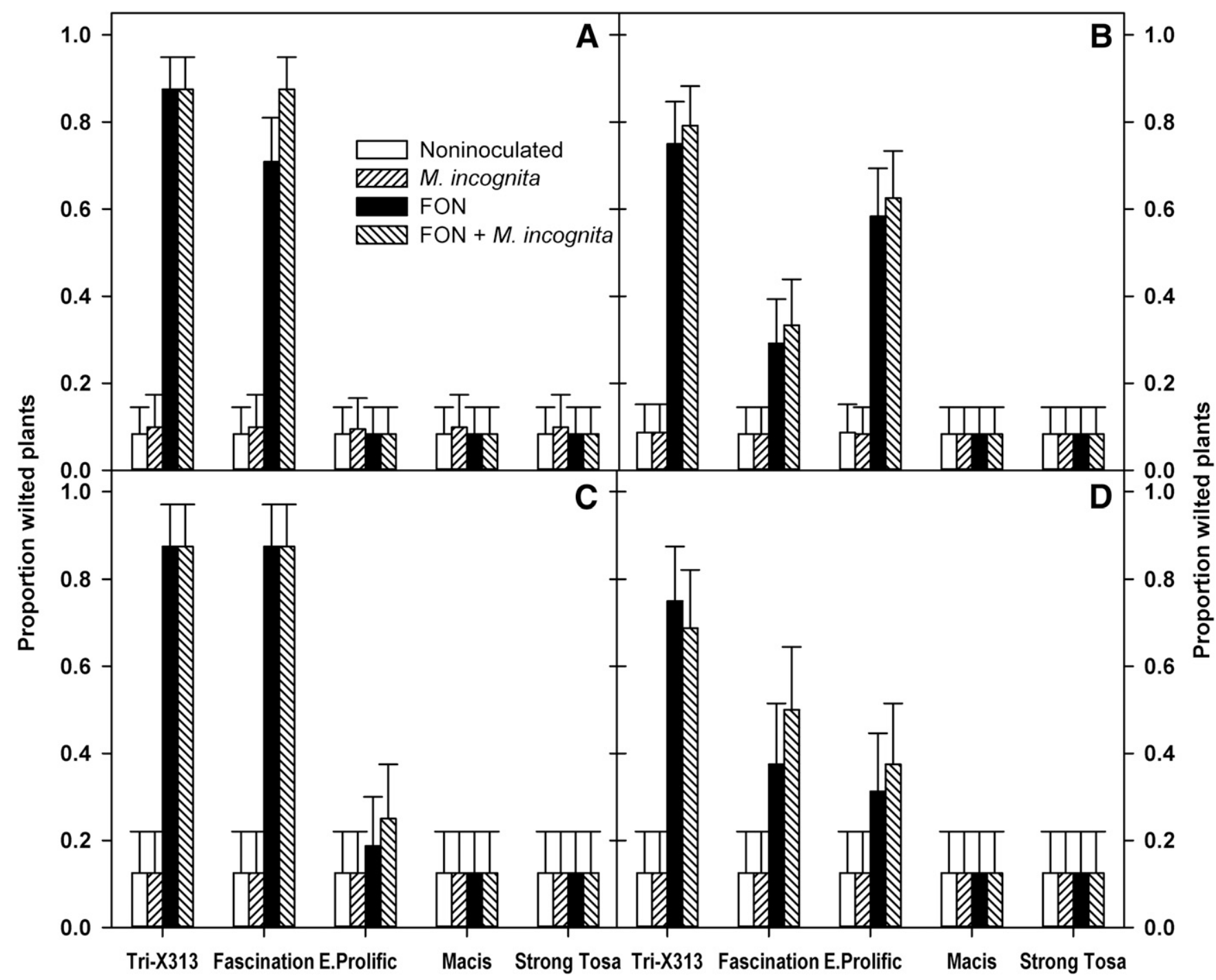

Fig. 2. Incidence of Fusarium wilt on five cucurbits inoculated with Fusarium oxysporum f. sp. niveum (FON) and Meloidogyne incognita in the greenhouse. Each graph shows the mean of two trials. A, F. oxysporum f. sp. niveum race 2, experiment one. B, F. oxysporum f. sp. niveum race 1, experiment two. C, F. oxysporum f. sp. niveum race 2, experiment three. D, F. oxysporum f. sp. niveum race 1, experiment three. Proportions were back-transformed weighted proportions used in categorical analysis of variance. Values $>0.85$ correspond to an incidence of 1.00 and values $<0.13$ correspond to an incidence of 0.00 . Proportions in A and B are based on 20 plants and proportions in $\mathrm{C}$ and $\mathrm{D}$ are based on 12 plants. Error bars show one standard error. 
Data from experiments one and three on Fusarium wilt incidence with $F$. oxysporum f. sp. niveum race 2 were combined for analysis. Results in the four trials did not differ significantly $\left(\chi^{2}, P=0.44\right)$, and there were no interactions of trial with host or pathogen treatment (Table 2). The host-pathogen interaction was highly significant $(P<0.0001)$. Wilt incidence was greater on all watermelon plants inoculated with $F$. oxysporum $\mathrm{f}$. sp. niveum race 2 , with or without $M$. incognita, than on plants not inoculated or inoculated with $M$. incognita only $(P<0.0001)$; however, wilt incidence did not differ among the four pathogen treatments for summer squash, bottle gourd, or interspecific hybrid squash $(P \geq 0.94)$. When hosts were inoculated with $F$. oxysporum $\mathrm{f}$. sp. niveum race 2 with or without $M$. incognita, wilt incidence was significantly greater for both watermelon cultivars than for the other three hosts $(P<0.0001)$. Wilt incidence with or without $M$. incognita did not differ between Tri-X 313 and Fascination inoculated with $F$. oxysporum $\mathrm{f}$. sp. niveum race $2(P \geq 0.28)$. Wilt incidence also did not differ among summer squash, bottle gourd, and interspecific hybrid squash $(P \geq 0.57)$ (Fig. 2A and C).

When inoculated with $F$. oxysporum $\mathrm{f}$. sp. niveum race 1 in experiments two and three, $>75 \%$ of the Tri-X 313 plants wilted, regardless of whether M. incognita was present (Fig. 2B and D). Fascination watermelon and Early Prolific Straightneck summer squash also wilted when inoculated with $F$. oxysporum $\mathrm{f}$. sp. niveum race 1 with or without $M$. incognita but proportions of wilted plants differed between the two experiments (Fig. 2B and D). No Macis bottle gourd or Strong Tosa interspecific hybrid squash plants wilted, regardless of pathogen inoculation.

Data from experiment two and data from the $F$. oxysporum f. sp. niveum race 1 treatments from experiment three were combined for analysis. Although the main effect of trial was significant $\left(\chi^{2}, P<\right.$ $0.04)$, there were no significant interactions of trial with host or pathogen treatment (Table 2). The host-pathogen interaction was

Table 2. Categorical analysis of variance for wilt incidence on five cucurbits coinoculated with Meloidogyne incognita and Fusarium oxysporum f. sp. niveum race 1 or race 2 in the greenhouse

\begin{tabular}{|c|c|c|c|}
\hline \multirow[b]{2}{*}{ Source of variation } & \multirow[b]{2}{*}{$d f^{x}$} & \multicolumn{2}{|c|}{$\begin{array}{c}\text { Probability of a greater } \\
\chi^{2} \text { value }\end{array}$} \\
\hline & & Race 1 & $\overline{\text { Race } 2}$ \\
\hline Intercept & 1 & 0.0001 & 0.0001 \\
\hline Trialy & 3 & 0.0389 & 0.4384 \\
\hline Host & 4 & 0.0001 & 0.0001 \\
\hline Trial-host & 12 & 0.9492 & 1.0000 \\
\hline Pathogen treatment ${ }^{\mathrm{z}}$ & 3 & 0.0001 & 0.0001 \\
\hline Trial-pathogen & 9 & 0.6109 & 0.9999 \\
\hline Host-pathogen & 12 & 0.0077 & 0.0001 \\
\hline Trial-host-pathogen & 36 & 1.000 & 1.0000 \\
\hline
\end{tabular}

${ }^{x}$ Degrees of freedom.

y There were four trials with each race. The third and fourth trials included both race 1 and race 2; data were separated by race for the combined analyses shown here.

${ }^{\mathrm{z}}$ The four pathogen treatments were $F$. oxysporum f. sp. niveum, $M$. incognita, both pathogens, and neither pathogen. significant $(P=0.0077)$. Wilt incidence did not differ among the four pathogen treatments for bottle gourd or interspecific hybrid squash $(P \geq 0.91)$ but pathogen treatments differed for Tri-X 313, Fascination, and Early Prolific Straightneck. Wilt incidence was greater on watermelon and summer squash inoculated with $F$. oxysporum f. sp. niveum race 1 , with or without $M$. incognita, than on plants not inoculated or inoculated with $M$. incognita only $(P<0.02)$ (Table 3). However, incidence did not differ on any host between treatments with $F$. oxysporum $\mathrm{f}$. sp. niveum race 1 and $F$. oxysporum f. sp. niveum race 1 plus $M$. incognita $(P \geq 0.56)$. Tri-X 313 had higher incidence of Fusarium wilt than Fascination, Strong Tosa, and Macis. Fascination had higher incidence than Strong Tosa and Macis (Table 3; Fig. 2B and D). Incidence on Early Prolific Straightneck summer squash did not differ from incidence on Tri-X 313 or Fascination but was greater than incidence on Strong Tosa and Macis (Table 3) $(P<0.02)$.

Wilt severity. Wilt severity data (i.e., the percentage of the foliage by area that was wilted) were analyzed for each experiment for Tri-X 313, Fascination, and Early Prolific Straightneck inoculated with $F$. oxysporum f. sp. niveum with and without $M$. incognita, because data with $F$. oxysporum $\mathrm{f}$. sp. niveum race 1 could not be combined across all trials (trial-host-pathogen interaction significant, $P=0.0031$ ). Wilt severity was 0 for all Macis bottle gourd and Strong Tosa interspecific hybrid squash plants and for all noninoculated plants and plants inoculated with $M$. incognita only; therefore, these host and pathogen treatments were excluded from the analysis to reduce inequality of treatment variances.

In all three experiments and with both $F$. oxysporum $\mathrm{f}$. sp. niveum races, there were no significant differences in wilt severity between inoculation with $F$. oxysporum f. sp. niveum or $F$. oxysporum $\mathrm{f}$. sp. niveum plus $M$. incognita (Fig. 3) (pathogen treatment $F$ statistics not significant, $P=0.17,0.07$, and 0.46 in experiments one, two, and three, respectively). The lack of treatment differences applied to all three hosts, because all host-pathogen interactions also were nonsignificant $(P=0.59,0.72$, and 0.20 in experiments one, two, and three, respectively). In addition, there was no race-treatment interaction in experiment three $(P=0.89)$. Thus, mean separations shown in Figure 3 are for hosts only.

Severity of Fusarium wilt differed by host in all three experiments $(P<0.0001)$. The host-race interaction also was significant in experiment three $(P<0.0001)$; therefore, hosts were compared within races (Fig. 3). With $F$. oxysporum f. sp. niveum race 2 in both experiments one and three, wilt severity on watermelon cultivars Tri-X 313 and Fascination was much greater than on summer squash $(P \leq$ 0.03). In experiment one, summer squash did not wilt when inoculated with $F$. oxysporum $\mathrm{f}$. sp. niveum race 2 , and mean wilt severity was $\leq 0.6 \%$ in experiment three (Fig. $2 \mathrm{~A}$ and C). Wilt severity on Tri$\mathrm{X} 313$ did not differ from severity on Fascination in experiment three $(P=0.03)$ but wilting was more severe on Tri-X 313 than Fascination in experiment one $(P=0.02)$. With $F$. oxysporum $\mathrm{f}$. sp. niveum race 1 in experiments two and three, wilting on Fascination, a watermelon cultivar resistant to $F$. oxysporum $\mathrm{f}$. sp. niveum race 1 , was less severe than on Tri-X 313, a cultivar susceptible to $F$. oxysporum f. sp. niveum race $1(P \leq 0.04)$ (Fig. $2 \mathrm{~B}$ and $\mathrm{C})$. Tri-X 313 also showed more wilting than summer squash in both experiments. Wilting was

Table 3. Incidence of Fusarium wilt on watermelon cultivars Tri-X 313 and Fascination and summer squash Early Prolific Straightneck coinoculated with Meloidogyne incognita and Fusarium oxysporum $\mathrm{f}$. sp. niveum race 1 or race 2 in the greenhouse ${ }^{\mathrm{z}}$

\begin{tabular}{lccccccc}
\hline & \multicolumn{2}{c}{ F. oxysporum f. sp. niveum race 1 } & & \multicolumn{2}{c}{ F. oxysporum f. sp. niveum race 2 } \\
\cline { 2 - 4 } \cline { 6 - 8 } Pathogen treatment & Tri-X 313 & Fascination & Early Prolific & & Tri-X 313 & Fascination & Early Prolific \\
\hline Noninoculated & $0.10 \pm 0.05$ b A & $0.10 \pm 0.05$ b A & $0.10 \pm 0.05$ b A & & $0.10 \pm 0.05$ b S & $0.10 \pm 0.05$ b S & $0.10 \pm 0.05$ a S \\
M. incognita & $0.10 \pm 0.05$ b A & $0.10 \pm 0.05$ b A & $0.10 \pm 0.05$ b A & & $0.11 \pm 0.06$ b S & $0.11 \pm 0.06$ b S & $0.11 \pm 0.06$ a S \\
F. oxysporum f. sp. niveum & $0.75 \pm 0.08$ a A & $0.37 \pm 0.09$ a B & $0.53 \pm 0.09$ a AB & & $0.88 \pm 0.06$ a T & $0.77 \pm 0.07$ a T & $0.12 \pm 0.06$ a S \\
M. incognita + F. oxysporum f. sp. niveum & $0.75 \pm 0.08$ a A & $0.40 \pm 0.09$ a B & $0.60 \pm 0.09$ a AB & $0.88 \pm 0.06$ a T & $0.88 \pm 0.06$ a T & $0.15 \pm 0.06$ a S \\
\hline
\end{tabular}

${ }^{\mathrm{z}}$ Each proportion is based on 32 plants. Values shown are back-transformed weighted proportions. Proportions $<0.13$ represent no wilted plants and proportions $>0.85$ represent $100 \%$ wilted plants. Means within a column with the same lowercase letter are not significantly different based on $\chi^{2}$ tests, $P \leq 0.02$ for $F$. oxysporum f. sp. niveum race 1 and $P \leq 0.0001$ for $F$. oxysporum $\mathrm{f}$. sp. niveum race 2 . Means within a row with the same uppercase letter are not significantly different based on $\chi^{2}$ tests, $P \leq 0.03$ for $F$. oxysporum $\mathrm{f}$. sp. niveum race 1 and $P \leq 0.0001$ for $F$. oxysporum $\mathrm{f}$. sp. niveum race 2 . 
more severe on summer squash than on Fascination in experiment two but wilting was more severe on Fascination than on summer squash in experiment three $(P=0.005)$.

Reisolation of F. oxysporum. In the final experiment that included both $F$. oxysporum f. sp. niveum races, frequency of reisolation of $F$. oxysporum did not differ significantly by trial $\left(\chi^{2}, P=0.72\right)$ or race $\left(\chi^{2}, P=0.93\right)$, and there were no significant interactions with these two factors; therefore, host and pathogen means were calculated across trial and race. The host-pathogen interaction was highly significant $\left(\chi^{2}, P=0.0008\right)$. $F$. oxysporum was reisolated more frequently from watermelon $\left(\chi^{2}, P \leq 0.0001\right)$ and summer squash $\left(\chi^{2}, P=0.02\right)$ plants inoculated with $F$. oxysporum $\mathrm{f}$. sp. niveum, with or without $M$. incognita, than from plants not inoculated with $F$. oxysporum f. sp. niveum (Table 4). Reisolation did not differ among pathogen inoculation treatments for bottle gourd and interspecific hybrid squash. When hosts were compared within pathogen inoculation treatments, reisolation frequency was greater for watermelon than for the other hosts inoculated with $F$. oxysporum $\mathrm{f}$. sp. niveum alone $\left(\chi^{2}, P=0.02\right)$ and with $F$. oxysporum f. sp. niveum plus $M$. incognita $(P=0.05)$. Reisolation frequency did not differ between

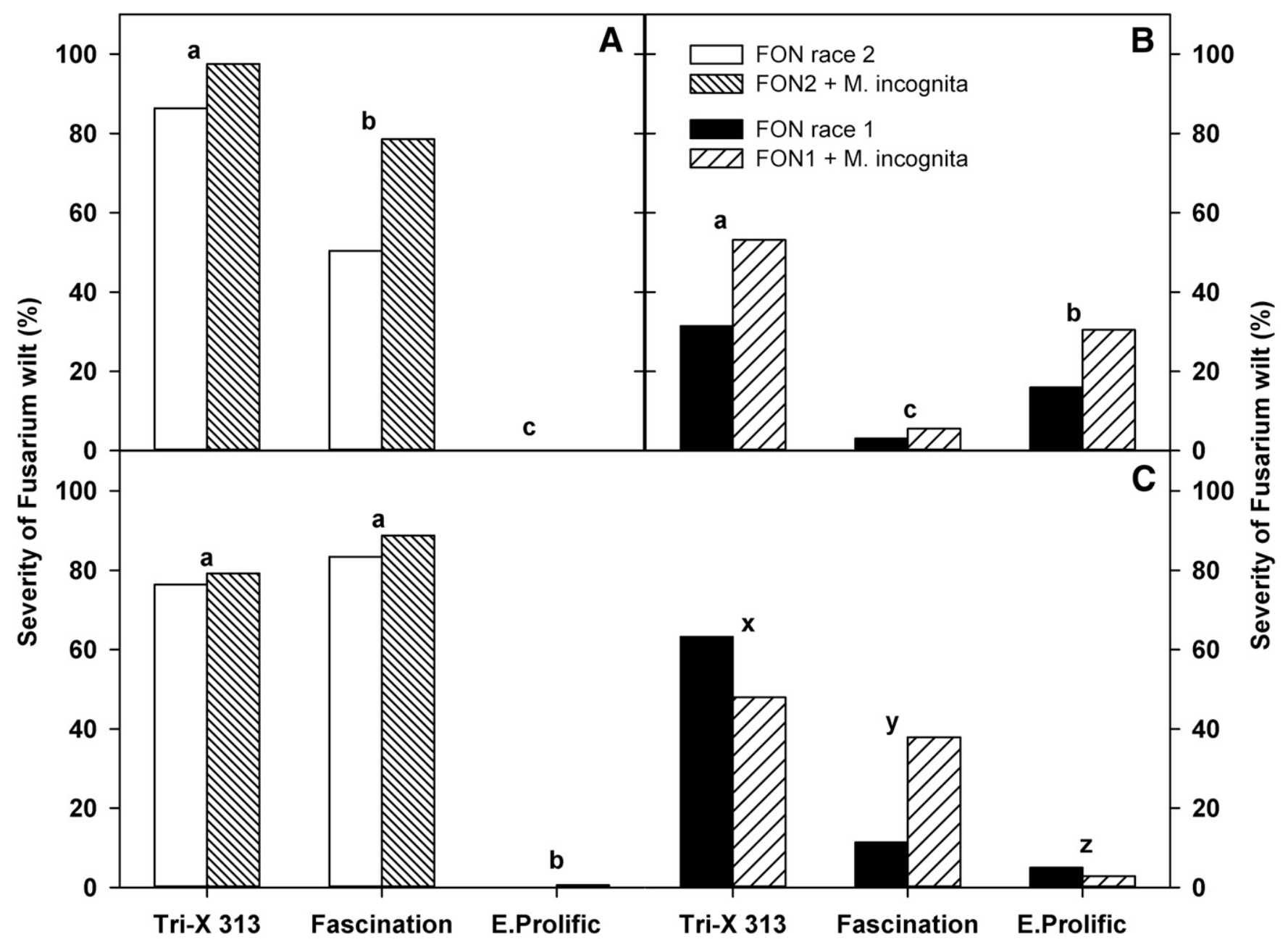

Fig. 3. Severity of Fusarium wilt on watermelon cultivars Tri-X 313 and Fascination and summer squash Early Prolific Straightneck inoculated with Fusarium oxysporum f. sp. niveum (FON) or M. incognita plus F. oxysporum f. sp. niveum in the greenhouse. Each graph shows the mean of two trials. $\mathbf{A}$, Experiment one with $F$. oxysporum f. sp. niveum race 2. Hosts with the same letters are not significantly different $(P \leq 0.005)$. B, Experiment two with $F$. oxysporum f. sp. niveum race 1 . Hosts with the same letters are not significantly different $(P \leq 0.02)$. C, Experiment three with $F$. oxysporum f. sp. niveum races 1 and 2 . Hosts with the same letters are not significantly different $(P=$ 0.0001 for race 2 and $P \leq 0.04$ for race 1). Treatment bars are not significantly different for any host in any experiment.

Table 4. Recovery of Fusarium oxysporum from stems of five cucurbits coinoculated with Meloidogyne incognita and Fusarium oxysporum f. sp. niveum race 1 or race 2 in the greenhouse ${ }^{\mathrm{y}}$

\begin{tabular}{lccccc}
\hline & \multicolumn{5}{c}{ Proportion of plants yielding $\boldsymbol{F}$. oxysporum } \\
\cline { 2 - 6 } Pathogen treatment & Tri-X 313 & Fascination & Early Prolific & Macis & Strong Tosa \\
\hline Noninoculated & $0.13(0.00)$ b A & $0.16(0.04)$ b A & $0.13(0.00)$ b A & $0.13(0.00)$ a A & $0.16(0.04)$ a A \\
M. incognita & $0.13(0.00)$ b A & $0.13(0.00)$ b A & $0.13(0.00)$ b A & $0.13(0.00)$ a A & $0.13(0.00)$ a A \\
F. oxysporum f. sp. niveum & $0.88(1.00)$ a A & $0.88(1.00)$ a A & $0.44(0.42)$ a B & $0.13(0.00)$ a C & $0.25(0.17)$ a BC \\
M. incognita + F. oxysporum f. sp. niveum & $0.88(1.00)$ a A & $0.81(0.92)$ a A & $0.53(0.54)$ a B & $0.13(0.00)$ a C & $0.25(0.17)$ a C \\
\hline
\end{tabular}

${ }^{\mathrm{y}}$ Cucurbit hosts were watermelon cultivars Tri-X 313 and Fascination, summer squash Early Prolific Straightneck, bottle gourd Macis, and interspecific hybrid squash Strong Tosa.

${ }^{\mathrm{z}}$ The host-pathogen treatment interaction was significant $\left(\chi^{2}, P=0.0008\right)$. Each proportion is based on 12 plants in each of two trials. Values shown are backtransformed weighted proportions with the original nontransformed proportions shown in parentheses. Means within a column with the same lowercase letter are not significantly different based on $\chi^{2}$ tests, $P \leq 0.0001$ for watermelon and $P=0.02$ for summer squash. Means within a row with the same uppercase letter are not significantly different based on $\chi^{2}$ tests, $P=0.02$ for $F$. oxysporum $\mathrm{f}$. sp. niveum and $P=0.05$ for $M$. incognita $+F$. oxysporum $\mathrm{f}$. sp. niveum. 
bottle gourd and interspecific hybrid squash inoculated with $F$. oxysporum $\mathrm{f}$. sp. niveum with or without $M$. incognita. Reisolation frequency was greater from summer squash than from bottle gourd and interspecific hybrid squash inoculated with $F$. oxysporum f. sp. niveum plus $M$. incognita $(P=0.05)$ and greater from summer squash than from bottle gourd inoculated with $F$. oxysporum $\mathrm{f}$. sp. niveum alone $(P=0.02)$.

\section{Discussion}

In all six experiments, neither wilt incidence nor wilt severity differed between plants inoculated with $F$. oxysporum $\mathrm{f}$. sp. niveum alone or with $F$. oxysporum $\mathrm{f}$. sp. niveum $+M$. incognita. When hosts were coinoculated at the same time with both pathogens, $F$. oxysporum f. sp. niveum likely was able to colonize more of the root system, or colonize it faster, than $M$. incognita, because microconidia of $F$. oxysporum f. sp. niveum germinate within 24 h (A. P. Keinath, unpublished). Thus, the root system of the $F$. oxysporum f. sp. niveumsusceptible host, watermelon, generally was smaller (root weight data not shown) and had fewer galls than the two rootstocks, both of which are resistant to $F$. oxysporum $\mathrm{f}$. sp. niveum (Keinath and Hassell 2014a,b). Seo and Kim (2017) also reported a lower rootgall index on watermelon coinoculated with $F$. oxysporum f. sp. niveum and $M$. incognita compared with $M$. incognita alone. Based on their histological examinations of roots, they concluded that, at a high inoculum density of $F$. oxysporum $\mathrm{f}$. sp. niveum, root cells became necrotic and nematode-induced giant cells were degraded and devoid of cytoplasm. Thus, it appears that $F$. oxysporum $\mathrm{f}$. sp. niveum may influence the severity of galling by $M$. incognita on susceptible watermelon cultivars.

In the experiments with single $F$. oxysporum $\mathrm{f}$. sp. niveum races, watermelon cultivars and races yielded typical results expected for combinations of virulent races on susceptible and resistant cultivars. With $F$. oxysporum f. sp. niveum, race-specific resistance is not absolute (i.e., resistant cultivars show fewer diseased plants when inoculated with an incompatible race than with a compatible race) (Hopkins et al. 1992; Martyn 2014; Zhou and Everts 2003). Thus, although some Fascination plants wilted when inoculated with race 1, a much greater number of Tri-X 313 plants wilted when inoculated with race 1 . As expected, wilt incidence and severity on Fascination inoculated with race 1 were lower than on Tri-X 313 inoculated with race 1.

Caperton et al. (1986) and Martyn and McLaughlin (1983a) investigated the susceptibility of Cucurbita spp. to F. oxysporum f. sp. niveum. As Martyn (2017) concluded, though, infection in the field is probably rare. Infection of inoculated squash by $F$. oxysporum f. sp. niveum is influenced by the host species, cultivar, inoculum concentration, and presence of $M$. incognita. In general, 10 of 29 summer squash and zucchini (C. pepo) cultivars were susceptible to $F$. oxysporum $\mathrm{f}$. sp. niveum race 1 , while single cultivars of $C$. moschata, C. maxima, C. ficifolia, C. argyrosperma (listed as C. mixta), and $C$. pepo (pumpkin) were resistant to $F$. oxysporum $\mathrm{f}$. sp. niveum race 1 (Martyn and McLaughlin 1983a). Wilt incidence was $>65 \%$ for four susceptible cultivars inoculated with $10^{5}$ or $10^{6}$ microconidia/ $\mathrm{ml}$, while incidence was $\leq 20 \%$ for two resistant cultivars (Caperton et al. 1986). When Early Prolific Straightneck and the resistant Goldneck were coinoculated with $F$. oxysporum $\mathrm{f}$. sp. niveum and $M$. incognita, wilt incidence on Early Prolific Straightneck appeared to increase significantly over time and was about double in the presence of both pathogens compared with $F$. oxysporum f. sp. niveum alone; however, no statistical analysis was reported (Caperton et al. 1986). In our experiments, Early Prolific Straightneck was moderately susceptible to race 1 of $F$. oxysporum $\mathrm{f}$. sp. niveum and resistant to race 2 of $F$. oxysporum $\mathrm{f}$. sp. niveum (Table 3 ), as defined by Martyn and McLaughlin (1983b). Coinoculation with $M$. incognita did not increase the wilt incidence, wilt severity, or recovery of $F$. oxysporum with either race. Thus, although we confirmed the susceptibility of Early Prolific Straightneck yellow summer squash to $F$. oxysporum f. sp. niveum race 1 and documented resistance to race 2 , we did not observe increased susceptibility in the presence of root-knot nematodes, even though our study and the study by Caperton et al. (1986) were conducted in greenhouses. It would be interesting to determine whether the resistance of Early Prolific Straightneck summer squash was consistently expressed to other isolates of $F$. oxysporum $\mathrm{f}$. sp. niveum race 2 .

Interspecific hybrid squash Strong Tosa and bottle gourd Macis were highly resistant to both races of $F$. oxysporum $\mathrm{f}$. sp. niveum, as reported previously (Keinath and Hassell 2014a). Likewise, Martyn and McLaughlin (1983a) and others have reported that C. maxima and C. moschata, the parent species of interspecific hybrid squash, are resistant to $F$. oxysporum f. sp. niveum. Coinfection of Strong Tosa and Macis by $M$. incognita and $F$. oxysporum f. sp. niveum did not alter the resistance to $F$. oxysporum $\mathrm{f}$. $\mathrm{sp}$. niveum in these two rootstocks. The lack of interaction between these two pathogens on resistant rootstocks is identical to the reaction of Goldneck summer squash inoculated with $M$. incognita and $F$. oxysporum f. sp. niveum race 1, as reported by Caperton et al. (1986), and similar to the reaction of chickpea to $F$. oxysporum $\mathrm{f}$. sp. ciceris and $M$. artiellia (Navas-Cortés et al. 2008).

Thies et al. (2010) evaluated several rootstocks for resistance to root knot in fields naturally infested with $M$. incognita. Several cultigens of bottle gourd had as much galling as Strong Tosa, and both rootstock species had more extensive galling than watermelon. In the current study, bottle gourd Macis consistently had less galling or as much galling as watermelon and less galling than Strong Tosa. It is possible that Macis is more resistant to Southern root-knot nematode than the cultivars tested by Thies et al. (2010). Galling on Macis also may have become more severe if the experiments had lasted 12 weeks, as long as the field experiments done by Thies et al. (2010). In both studies, Strong Tosa was among the cultivars most susceptible to M. incognita.

In summary, we found no evidence that a watermelon cultivar resistant to $F$. oxysporum $\mathrm{f}$. sp. niveum race 1 or cucurbit rootstocks with nonhost resistance to $F$. oxysporum $\mathrm{f}$. sp. niveum races 1 and 2 would become susceptible to $F$. oxysporum f. sp. niveum if they were coinfected with $F$. oxysporum $\mathrm{f}$. sp. niveum and $M$. incognita. The severe galling on Strong Tosa interspecific hybrid squash and moderately severe galling on watermelon and Macis bottlegourd provided a sufficient level of galling to influence susceptibility to Fusarium wilt if an interaction between $M$. incognita and $F$. oxysporum f. sp. niveum existed on cucurbits. In one of three experiments done by Thies et al. (2010), galling on grafted Strong Tosa and Emphasis bottle gourd was severe enough to reduce the number of watermelon fruit compared with the nongrafted control. Thus, it may be necessary to apply a nematicide to manage root knot galling on watermelon grafted onto interspecific hybrid squash or bottle gourd planted in soil infested with populations of $M$. incognita over the treatment threshold of $10 \mathrm{~J} 2$ per $100 \mathrm{~cm}^{3}$ of soil.

\section{Literature Cited}

Bell, A. A., Kemerait, R. C., Ortiz, C. S., Prom, S., Quintana, J., Nichols, R. L., and Liu, J. 2017. Genetic diversity, virulence, and Meloidogyne incognita interactions of Fusarium oxysporum isolates causing cotton wilt in Georgia. Plant Dis. 101:948-956.

Caperton, C. M., Martyn, R. D., and Starr, J. L. 1986. Effects of Fusarium inoculum density and root-knot nematodes on wilt resistance in summer squash. Plant Dis. 70:207-209.

Davis, A. R., Perkins-Veazie, P., Sakata, Y., Lopez-Galarza, S., Maroto, J. V., Lee, S. G., Huh, Y. C., Sun, Z., Miguel, A., King, S. K., Cohen, R., and Lee, J. M. 2008. Cucurbit grafting. Crit. Rev. Plant Sci. 27:50-74.

Hopkins, D. L., Lobinske, R. J., and Larkin, R. P. 1992. Selection for Fusarium oxysporum $\mathrm{f}$. sp. niveum race 2 in monocultures of watermelon resistant to Fusarium wilt. Phytopathology 82:290-293.

Keinath, A. P., and Hassell, R. L. 2014a. Control of Fusarium wilt of watermelon by grafting onto bottlegourd or interspecific hybrid squash despite colonization of rootstocks by Fusarium. Plant Dis. 98:255-266.

Keinath, A. P., and Hassell, R. L. 2014b. Suppression of Fusarium wilt caused by Fusarium oxysporum $\mathrm{f}$. sp. niveum race 2 on grafted triploid watermelon. Plant Dis. 98:1326-1332.

Kemble, J. M., Meadows, I. M., Jennings, K. M., and Walgenbach, J. F., eds 2017. Southeastern U.S. Vegetable Crop Handbook, Revised. Farm Journal Media, Lenexa, KS.

Kleczewski, N. M., and Egel, D. S. 2011. A diagnostic guide for Fusarium wilt of watermelon. Online publication. Plant Health Prog. doi.org/10.1094/PHP2011-1129-01-DG 
Komada, H. 1975. Development of a selective medium for quantitative isolation of Fusarium oxysporum from natural soils. Rev. Plant Prot. Res. 8:114-124.

Martyn, R. D. 2014. Fusarium wilt of watermelon: 120 years of research. Hortic. Rev. (Am. Soc. Hortic. Sci.) 42:349-442.

Martyn, R. D. 2017. Fusarium wilt of watermelon. Pages 38-40 in: Compendium of Cucurbit Diseases and Pests, 2nd ed. A. P. Keinath, W. M. Wintermantel, and T. A. Zitter, eds. American Phytopathological Society Press, St. Paul, MN.

Martyn, R. D., and McLaughlin, R. J. 1983a. Susceptibility of summer squash to the watermelon wilt pathogen (Fusarium oxysporum f. sp. niveum). Plant Dis. 67:263-266

Martyn, R. D., and McLaughlin, R. J. 1983b. Effects of inoculum concentration on the apparent resistance of watermelons to Fusarium oxysporum $\mathrm{f}$. sp. niveum. Plant Dis. 67:493-495.

Miguel, A., Varoto, J. V., San Bautista, A., Baizauli, C., Cebolla, V., Pascual, B., López, S., and Guardiola, J. L. 2004. The grafting of triploid watermelon is an advantageous alternative to soil fumigation by methyl bromide for control of Fusarium wilt. Sci. Hortic. (Amsterdam) 103:9-17.

Naji, I., and Abu-Gharbieh, W. 2004. Effect of Meloidogyne javanica and M. incognita on resistance of muskmelon cultivars to Fusarium wilt. Phytopathol. Mediterr. 43:360-368.

Navas-Cortés, J. A., Landa, B. B., Rodríguez-López, J., Jiménez-Díaz, R. M., and Castillo, P. 2008. Infection by Meloidogyne artiellia does not break down resistance to races $0,1 \mathrm{~A}$, and 2 of Fusarium oxysporum $\mathrm{f}$. sp. ciceris in chickpea genotypes. Phytopathology 98:709-718.

Noling, J. W. 2014. Root-knot nematodes. Pages 114-118 in: Compendium of Tomato Diseases and Pests, 2nd ed. J. B. Jones, T. A. Zitter, T. M. Momol, and S. A. Miller, eds. American Phytopathological Society Press, St. Paul, MN.
Santner, T. J., and Duffy, D. E. 1989. The Statistical Analysis of Discrete Data. Springer-Verlag, New York.

Schabenberger, O., and Pierce, F. J. 2002. Contemporary Statistical Models for the Plant and Soil Sciences. Taylor \& Francis, Boca Raton, FL.

Seo, Y., and Kim, Y. H. 2017. Pathological interrelations of soil-borne diseases in cucurbits caused by Fusarium species and Meloidogyne incognita. Plant Pathol. J. 33:410-423.

Sumner, D. R., and Johnson, A. W. 1973. Effect of root-knot nematodes on Fusarium wilt of watermelon. Phytopathology 63:857-861.

Thies, J. A. 2017. Root-knot nematodes. Pages 156-157 in: Compendium of Cucurbit Diseases and Pests, 2nd ed. A. P. Keinath, W. M. Wintermantel, and T. A. Zitter, eds. American Phytopathological Society Press, St. Paul, MN.

Thies, J. A., Ariss, J. J., Hassell, R. L., Olson, S., Kousik, C. S., and Levi, A. 2010 Grafting for management of southern root-knot nematode, Meloidogyne incognita, in watermelon. Plant Dis. 94:1195-1199.

Wechter, W. P., Kousik, C., McMillan, M., and Levi, A. 2012. Identification of resistance to Fusarium oxysporum $\mathrm{f}$. sp. niveum race 2 in Citrullus lanatus var. citroides plant introductions. HortScience 47:334-338.

Yetışır, H., Sari, N., and Yücel, S. 2003. Rootstock resistance to Fusarium wilt and effect on watermelon fruit yield and quality. Phytoparasitica 31:163-169.

Zhou, X. G., and Everts, K. L. 2003. Races and inoculum density of Fusarium oxysporum f. sp. niveum in commercial watermelon fields in Maryland and Delaware. Plant Dis. 87:692-698.

Zhou, X. G., Everts, K. L., and Bruton, B. D. 2010. Race 3, a new and highly virulent race of Fusarium oxysporum $\mathrm{f}$. sp. niveum causing Fusarium wilt in watermelon. Plant Dis. 94:92-98. 